\title{
Unfair incentives: A behavioural note on sharecropping ${ }^{1}$
}

\author{
Niels Kemper*, Kristina Czura** and Heiner Schumacher ${ }^{\star \star *}$ \\ *KfW Development Bank, Competence Center for Development, Governance and Peace. E-mail: \\ niels.kemper@kfw.de \\ **Department of Economics, University of Munich. E-mail: kristina.czura @econ.Imu.de \\ ***Department of Economics, KU Leuven, Naamsestraat 69 3000Leuven, Belgium. E-mail: \\ heiner.schumacher@kuleuven.be
}

\section{Abstract}

We conducted a laboratory-in-the-field experiment with real-life tenants in Ethiopia to test the incentive effects of fixed wage, sharecropping, fixed rent, and ownership contracts. The experimental task resembles a common process in agricultural production. The sharecropping contract is a piece rate scheme framed as a profit-sharing agreement. Sharecropping output was about 12 percent smaller than the fixed rent output. Surprisingly, it is statistically indistinguishable from the fixed wage output, despite substantial piece rates. This effect is driven by real-life sharecroppers. Their sharecropping output was smaller than that of non-sharecroppers, especially in a region where a controversial land reform took place. We argue that our subjects dislike sharecropping contracts because of the unfair profit sharing and the disputed

Received: November 28, 2016; Acceptance: December 7, 2017

${ }^{1}$ We express our gratitude to the Stiftungsfond of the Deutsche Bank for funding this field research and to Rainer Klump from the Goethe University in Frankfurt, Germany, for assistance in writing the research proposal. We are also grateful to Tekie Alemu and Tadele Ferede from the School of Economics at Addis Ababa University, Ethiopia, for their intellectual, logistic, and administrative support of the research project. We are indebted to the field supervisor Getachew Andane as well as the enumerators Kassahun Alemayehu, Alem Brhanemeskel, Sisay Addis, Yeshi Mulatu, Fetene Belayhum, Ermias Samuel, Hibiret Tsehay, Daniel Mekonnen and Awoke Yalew for their diligent and thorough field work. We also thank Alexandra Roulet (the Editor), two anonymous referees and conference participants at the CSAE Conference 2012 'Economic Development in Africa' and the 2015 Land and Poverty Conference for their valuable comments and suggestions. The usual disclaimer applies. This paper reflects the opinion of its authors and neither relates to the operations of the KfW nor does it represent the position of the KfW. 
allocation of land. Fairness concerns, therefore, may be another impediment to efficiency under the sharecropping contract.

Keywords: Agricultural contracts, Ethiopia, fairness.

JEL classifications: C93, J30, N50.

\section{Introduction}

There are four main cases of how to contract land and labour, and hence the claim to the yields from the land: wage labour, sharecropping, fixed rent and owner cultivation. The term sharecropping refers to a contractual relationship between a landlord and a tenant allowing the latter to use the land of the former in return for a share of the crops produced on this land. The discussion of the negative incentive effects of sharecropping is almost as old as the discipline of economics. Adam Smith and John Stuart Mill were early proponents of the English fixed rent leasehold tenancy vis-à-vis the French métayage (share tenancy). Alfred Marshall argues along the same lines in Principles of Economics, claiming that sharecropping leads to an undersupply of effort, as tenants receive only a fraction of their marginal output. ${ }^{2}$

Empirical evidence on the 'Marshallian inefficiency' is usually gathered by evaluating input intensities for farmers who sharecrop and own (or sharecrop and rent) at the same time, see Binswanger and Rosenzweig (1986), Shaban (1987), and Laffont and Matoussi (1995). However, the motive for sharecropping a plot, rather than choosing another contractual form, is hard for the econometrician to evaluate in observational data. ${ }^{3}$ In particular, this is true if preference-driven matching processes are considered (Ackerberg and Botticini, 2002). Farmer characteristics such as ability, risk and time preferences, but also environmental conditions (soil quality, differences in moisture, patterns of water runoff) are difficult to observe. They bias the estimates if they correlate with the contract choice and input intensities in the crop production process. The literature has addressed these concerns by neutralizing time-invariant farmer characteristics through the comparison of sharecropped and owned plots for the same farmer (Bell, 1977); or by differencing away unobserved land heterogeneity through spatial fixed-effects (Goldstein and Udry, 2008), ${ }^{4}$ plot-fixed effects (Newman et al., 2015), or landlord-tenant pair fixed-effects (Deininger et al., 2013).

In this paper, we employ a laboratory-in-the-field experiment to circumvent these biases and to counterfactually estimate the incentive effects of fixed wage,

2 The references are Alfred Marshall (1890): Principles of Economics, Adam Smith (1776): Wealth of Nations, and John Stuart Mill (1848): Principles of Political Economy.

${ }^{3}$ Contract theory identifies a number of mechanisms rendering sharecropping a preferable contract option. These are risk-sharing, moral hazard on the part of the tenant, financing constraints, and screening among tenant types (see Singh, 1989 for a comprehensive review).

${ }^{4}$ This study is not on the incentive effects of sharecropping, but on the relationship between land rights and agricultural investment. However, the identification strategy could equally well be applied to estimate the impact of agricultural contracts on the choice of input intensities under unobserved land heterogeneity. 
sharecropping, fixed rent, and ownership contracts. The experimental method allows us to randomly assign subjects to contracts and thereby to avoid endogeneity problems. Our subjects are a representative sample of farmers in rural Ethiopia (from the regions of Amhara and Oromia), a country highly dependent on agriculture and possessing a widespread culture of sharecropping. ${ }^{5}$ The experimental task resembles a common agricultural task: collecting beans of a particular colour out of a bucket filled with multicoloured beans. Performance is measured by the weight of beans the subjects separated from the rest within a given period of time. The earnings in the experiment correspond to the typical daily expenditures of our subjects.

In the sharecropping treatment, subjects' payments increase in their performance, but they have to pay back half of their earnings for being allowed to participate in the task; in the fixed wage treatment, they earn a fixed fee, regardless of their output; in the fixed rent treatment, subjects earn the full value of their output and pay a fixed rent for being allowed to participate in the task; in the ownership treatment, they earn the full value without deductions.

We get two main results. First, we find - as expected - that the average output under full marginal returns (in the fixed rent and ownership treatment) is significantly larger than in the sharecropping treatment. Compared to the fixed rent treatment, the incentive effect of sharecropping is about 12 percent. As Table 1 shows, this number is comparable to those typically found in survey data for Ethiopia (Deininger et al., 2008, 2011; Pender and Fafchamps, 2006).

Second, we find - unexpectedly - no significant difference in the average output between the fixed wage and the sharecropping treatment, despite a relatively small fixed wage (subjects earn the same amount in both treatments if they produce a relatively small quantity) and a substantial piece rate in the sharecropping treatment. This is remarkable, given that the empirical literature which analyzes productivity differences between fixed wage and piece rate schemes consistently finds large increases in productivity of the order of 20 percent.

We observe that the subjects' background matters for real-effort output under the sharecropping treatment. Subjects who work under sharecropping incentives in their real life produce significantly less in this treatment than non-sharecroppers. Under any other treatment, there is no significant difference in output between reallife sharecroppers and non-sharecroppers. Hence, the differences in the sharecropping output cannot be attributed to ability. This effect is especially pronounced in the region of Amhara. Real-life sharecroppers in this region even produce around 12

5 In our sample, 47 percent of all households have at least one plot under a sharecropping arrangement, and 21 percent have at least one plot under a fixed rent arrangement. Deininger et al. (2011) find that between 31 and 49 percent of all households with land titles participate in land markets, and between 20 and 37 percent of all households without land titles participate in land markets (the paper does not distinguish between fixed rent and sharecropping contracts in rental markets). Looking at the plot level rather than the household level, Pender and Fafchamps (2006) find that 10 percent of the plots in their sample are under a sharecropping arrangement, while 21 percent are under a fixed rent arrangement. Deininger et al. (2008) find that 22 percent of plots in their sample are under a sharecropping arrangement. 


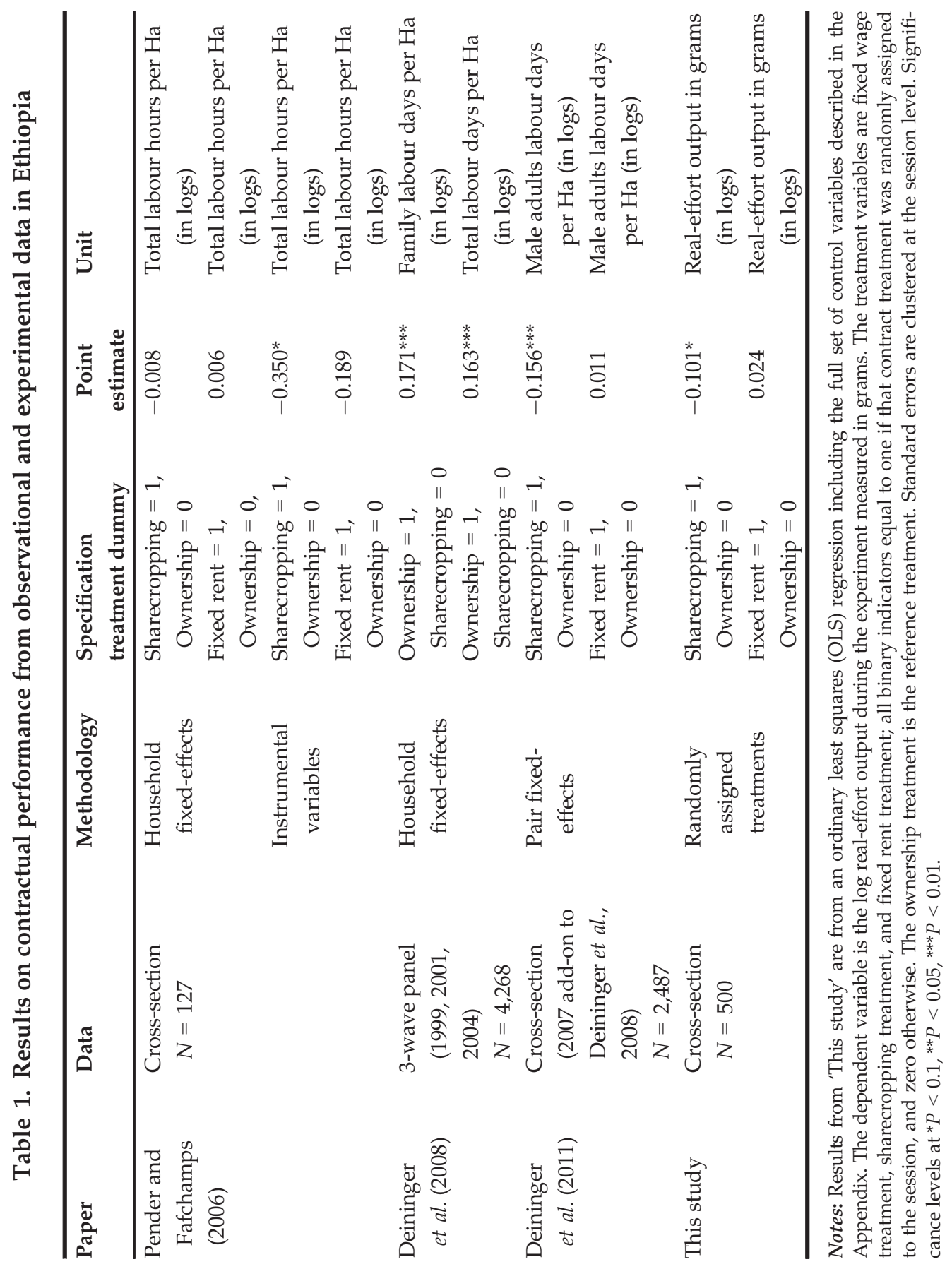

(c) 2018 The Authors 
percent less output in the sharecropping treatment than in the fixed wage treatment. It is impossible to explain this finding from a pure incentive perspective.

To reconcile the second main result, we analyze the qualitative interviews we conducted after the experiment and draw on historical accounts. We note substantial dissatisfaction of our subjects with sharecropping arrangements. Many real-life sharecroppers complained about the unfair profit-sharing where the landowner does not contribute work or other inputs. Such complaints were especially prevalent in Amhara where, in 1997, a highly controversial land reform took place. For political reasons, the reform favoured some groups, deprived others, and in its aftermath pushed a substantial number of peasants out of subsistence agriculture and into land markets. Historical accounts (Ege, 1997, 2002) report widespread corruption. In the interviews, a number of subjects from Amhara complained that today's landlords are those who bribed officials in order to manipulate the allocation of land.

Based on these insights, we provide the following explanation for our second main result: the sharecropping treatment reminds real-life sharecroppers of the unfair profit-sharing agreement they are exposed to in their real-life contract. In Amhara, it further reminds them of the unfair distribution of land in their community. Both effects lower their effort motivation, so that real-life sharecroppers produce less output in the sharecropping treatment than non-sharecroppers, especially in Amhara.

In light of this explanation, our second result suggests the following general lesson. There are two aspects to optimal contracts: monetary incentives and fairness. We conjecture that fairness concerns matter for the performance of sharecropping contracts since profit-sharing ties the landlord's payoff to the tenant's effort. Fairness concerns can be an additional impediment to efficiency in sharecropping, making it (in our case) no more useful than having no monetary incentives at all. As far as we know, this behaviourial aspect of sharecropping has not been examined yet.

The rest of this paper is organized as follows. In the next section, we describe the related literature. Section 3 explains the experimental design and procedures. In Section 4, we examine the experimental results. In Section 5, we provide an interpretation of the results based on qualitative interviews with our subjects and historical accounts. Section 6 concludes and discusses potential avenues for future research. The Appendix contains the instructions of the experiment. An online Appendix contains further robustness checks and materials.

\section{Related literature}

This paper is related to the empirical contract theory literature and to a recent literature in development economics that studied the impact of societal context on economic behaviour. 


\subsection{Effectiveness of incentives}

It is by now standard to evaluate the incentive effects of different contractual arrangements using laboratory and field experiments. A large number of laboratory experiments show how social preferences impact the shape of optimal contracts (see Charness and Kuhn, 2011, for a review). Bandiera et al. (2005) use data from a large farm in the UK to compare the performance of relative incentive and piece rate contracts. They find that productivity under piece rates is 60 percent larger than under relative incentives (where a worker's output has a negative effect on her co-workers' wages). Gneezy and List (2006) use data entry and fundraiser jobs to study the incentive effects of unexpected gifts. They find a positive effect of gifts on performance, which however vanishes over time. Cohn et al. (2015) demonstrate that workers with reciprocal preferences who initially feel underpaid respond positively to a wage increase. Breza et al. (forthcoming) show that pay differences among manufacturing workers reduce output and attendance when perceived as unfair. The present paper suggests that the societal context may matter for the effectiveness of incentives, in particular when profits are shared between principal and agent.

A number of papers compare the performance of piece rate and fixed wage contracts. In his famous Safelite study, Lazear (2000) finds a 44 percent increase in productivity when the payment scheme changes from hourly wages to piece rates. One-half of the effect can be attributed to an increase in the effort on the part of the average worker. Shearer (2004) uses data from a tree-planting firm that randomly assigned fixed wages or piece rates to a subset of workers. He observes a 20 percent increase in productivity. Shi (2010) conducted field experiments in a tree-thinning setting and found similar differences in contractual performance between fixed wage and piece rate compensations. In contrast, piece rates in our experiment do not increase performance when we framed them as a sharecropping contract. In a field experiment with young tenants in Uganda, Burchardi et al. (2017) find that reducing the landlord's share in the sharecropping contract from 50 percent to 25 percent increases the sharecropping output by 60 percent.

Our interpretation of the low sharecropping output result is based on a recent literature that shows how the framing of incentive contracts can influence productivity. Blanes-i-Vidal and Nossol (2011) make the relative position in the pay and productivity distribution salient to the workers of a large retail company. This led to a lasting 6.6 percent increase in productivity. Hossain and List (2012) frame contingent incentives in a Chinese factory as gains or losses. This manipulation leads to a 1 percent increase in team productivity. Englmaier et al. (2017) increase the salience of quantity incentives at a large agricultural producer and find a significant 4 percent increase in output. 


\subsection{Incentives and context}

Several recent papers show that the societal context influences economic decisionmaking in various domains. Benjamin et al. (2010) use a background questionnaire to prime social identity (Asian-American vs. white American). They find that making social identity salient to Asian-American subjects makes them more patient in a choice task, while there is no such effect for white American subjects. Hoff and Pandey $(2006,2014)$ show that making low-caste identity salient to students reduces their intellectual performance. Czura (2015) conducts a microcredit laboratory-in-the-field experiment in rural India and finds excessive punishment of repayment failure. This mirrors real-life behaviour in group-lending microcredit contracts and is difficult to explain with the incentives of the experimental setting. Vollan et al. (2017) analyze the behaviour of Chinese students and workers in public goods games and find that the level of cooperation is highest in an authoritarian environment (where a punishment mechanism is implemented exogenously), which is in line with the locally prevailing authoritarian norms. To the best of our knowledge, this paper is the first experimental study on the incentive effects of sharecropping contracts that comments on the link between societal context and contractual performance of sharecropping.

\section{Experimental design}

\subsection{Sampling}

The study sites were selected in three stages. First, we defined the sample universe to consist of households in Amhara and Oromia, the two economically most active and most populated regions in Ethiopia. Then we sampled two districts ('Woredas') in each region (Gozamen and Bahir Dar Zuria in Amhara, Adaa and Girar Jarso in Oromia). Districts are composed of peasant associations ('Kebeles'), which are the smallest administrative unit in Ethiopia. We randomly selected Kebeles within Woredas, five in Adaa, five in Girar Jarso, eight in Gozamen and seven in Bahir Dar Zuria. ${ }^{6}$

Census data on the different Ethiopian Kebeles are not always up to date. Hence, for the sampling of households at the Kebele level, we drew on registers kept by Kebele chiefs. These registers are widely thought to be up to date, as claims to land are documented in them. Randomization at the Kebele level was done by dividing the $N$ households living in the Kebele by 22 (for 20 peasants and 2 replacements in case the sampled peasants do not show up) and then inviting every $N / 22$ nd household head from the list. We invited the head rather than a randomly selected

\footnotetext{
${ }^{6}$ Sampling by clusters in this three-stage design generates a sample in which households are grouped geographically. Since the clusters vary in population size, the households are sampled with unequal selection probabilities. In the paper, we show the results from unweighted regressions. In the online Appendix, we examine the same regressions with population-weights to take into account unequal selection probabilities. All findings presented in the paper are robust to this change in the specification.
} 
household member, because the experiment was accompanied by a detailed quantitative and qualitative household survey, and household heads were considered the most appropriate person to supply this information.

The data collection took place in May 2011 before the start of sowing at the beginning of the crop cycle. Household heads could thus spare time to participate in our data collection. Upon invitation, they were told that they could earn an unspecified amount of money during a research visit from a team from Addis Ababa University. The enumerators had to refer to the replacement household heads in very few cases.

\subsection{Design}

The real-effort task was a sorting task that resembles an agricultural production process typical for Ethiopia. ${ }^{7}$ Each participant received two buckets: a flat blue bucket with a diameter of $22 \mathrm{~cm}$ and a raised red bucket with a diameter of $16 \mathrm{~cm}$. At the beginning of the experiment, the blue bucket was filled with $700 \mathrm{~g}$ of beans of three different colours (red, yellow and white), while the red bucket was empty. We asked peasants to collect as many beans of a particular colour as they could and put them into the red bucket. They had 15 minutes for this task. ${ }^{8}$ Performance was measured as the weight of beans the peasants manage to separate. ${ }^{9}$

The real-effort task was conducted under four different contract treatments: fixed wage, sharecropping, fixed rent and ownership. The treatments were randomly assigned across sessions. Each peasant participated only in one treatment and we provided no information about the existence of other treatments. Let $x$ denote the real-effort output in grams. In the fixed wage ( $f w$ ) treatment, the peasants were compensated with the fixed amount of 20 Birr. ${ }^{10}$ Enumerators emphasized that their payment was independent of their output. Hence, a peasant's payoff in the fixed wage treatment was:

$$
m=20 \text { Birr. }
$$

\footnotetext{
${ }^{7}$ Here are two examples. First, coffee is Ethiopia's main export crop. Dry processing of coffee beans is common. The first step in processing coffee is cleaning, which involves winnowing done by hand using a sieve. In the process, the berries are sorted, and cleaned from dirt, soil, twigs and leaves. Unwanted berries are picked out from the top of the sieve and removed. Second, fruit plantations such as avocado, banana, citrus, grape, pineapple, papaya, mango, peach and apples are also quite common in Ethiopia. Pests of fruit crops are a major problem in all areas of fruit production, as fruit flies are attracted by ripening or fermenting fruit. One way of dealing with fruit flies is sorting and separating ripe from unripe fruit after harvest.

${ }^{8}$ Clearly, this amount of time is quite short when compared to the time investment required in agricultural production. However, to measure the pure incentive effect of sharecropping it is essential to mitigate peer effects (see also our discussion of the experimental procedures below). If the real-effort task would have taken much longer, subjects may have started to communicate with each other, thereby creating peer effects that dilute our results.

9 The online Appendix contains pictures of the coloured beans and the experimental equipment.

10 At the time of the data collection, the exchange rate was roughly 1 Birr $=0.06$ USD.
} 
In the sharecropping (sh) treatment, enumerators told the peasants that they earn 40 Birr for every $100 \mathrm{~g}$ of output, but that they also have to return half of this payment to us for being allowed to participate in the task. ${ }^{11}$ A peasant's payoff in the sharecropping treatment was:

$$
m=x \times 0.2 \text { Birr. }
$$

This compensation is essentially a piece-rate scheme. However, in contrast to sharecropping arrangements, piece rates are not a common form of contracting for our subjects. The wording of our instructions highlighted the profit-sharing character of the incentive contract. Moreover, an equal split of the output between the landlord and the tenant is commonly observed in real-life sharecropping arrangements.

In the fixed rent ( $f r)$ treatment, enumerators announced that peasants earn 40 Birr for every $100 \mathrm{~g}$ of output, but that they have to pay 20 Birr for being allowed to participate in the task. A peasant's payoff in the fixed rent treatment was:

$$
m=x \times 0.4 \text { Birr }-20 \text { Birr. }
$$

Finally, in the ownership (ow) treatment, peasants earned 40 Birr for every $100 \mathrm{~g}$ of output. Thus, a peasant's payoff in the ownership treatment was

$$
m=x \times 0.4 \text { Birr. }
$$

These payment schemes were not chosen arbitrarily. In non-incentivized preparatory sessions with enumerators and students, the average output was $110 \mathrm{~g}$. We chose the payoff structure for each treatment to avoid inappropriate scaling of the fixed wage influencing real-effort output. For $100 \mathrm{~g}$, the payoff in the first three treatments is 20 Birr, and in the ownership treatment it is 40 Birr. This is a sizeable amount of money given that the average monthly per-capita expenditure of our subjects was 721 Birr (around 24 Birr per day so that in the 15-minutes experiment, subjects could easily earn more than their daily expenditure). ${ }^{12}$

\subsection{Predictions}

The experimental design allows us to compare the incentive effects of the four different contract arrangements. Denote by $x_{i}$ the average output in treatment $i$. Since the marginal payoffs are equal in the fixed rent and ownership treatments, we expect the average output in both treatments to be equal:

$$
x_{f r}=x_{o w} .
$$

11 The instructions for all treatments are in the Appendix.

12 Table A1 in the online Appendix contains descriptive statistics on the per-capita expenditure levels. It also presents some correlations between the choice of real contracts and per-capita expenditure levels. 
The incentive effect of sharecropping is measured by the difference between the average output in the fixed rent treatment and the average output in the sharecropping treatment. We conjecture that this difference is strictly positive:

$$
\text { Incentive effect of sharecropping }=x_{f r}-x_{s h}>0 \text {. }
$$

In the preparatory sessions, the average fixed wage output exceeded $100 \mathrm{~g}$. Hence, peasants earn more in the sharecropping treatment than in the fixed wage treatment if they exert the same effort as the subjects in the preparatory sessions. In the sharecropping treatment, they have an incentive to produce more output. Hence, we conjecture that the average output in the sharecropping treatment significantly exceeds the average output in the fixed wage treatment:

$$
x_{s h}>x_{f w} .
$$

\subsection{Experimental procedures}

Each session was organized as follows. We arrived in the village and met the local organizers. Then we met with the sampled peasants in venues such as communal centres or health centres. After the enumerators introduced themselves, a text was read to the peasants (by the same enumerator in all sessions). Peasants were allowed to quit the experiment at any time if they felt uncomfortable with it. However, all of them chose to complete the task.

To rule out peer effects, ${ }^{13}$ we adopted the following protocol. The enumerators arranged for the peasants to sit in a circle with adequate distances between them (the experiment was conducted outside, on meadows, to have enough space). ${ }^{14}$ They asked peasants to turn so that their backs were facing the inside of the circle. To make sure that peasants did not hear each other performing the task, the enumerators covered the bottom of the bucket with a paper towel so that the beans did not produce a sound when they were dropped into the bucket. To prevent peasants from hearing each other, enumerators also turned on music on portable speakers (the music was the same in all sessions).

During the real-effort task, the enumerators stood inside the circle making sure that the peasants did not turn their heads to watch each other. After the allotted time was up, they collected the red buckets from the peasants and weighed their content on a scale. To detect cheating, beans were weighted in a transparent bowl (there was, however, not a single incident of cheating). The payoffs were determined according to the type of contract and the weight achieved. After the real-effort task,

\footnotetext{
13 The peasants might increase their efforts if they watched other peasants exercise a high effort, or the reverse, see Falk and Ichino (2006), Mas and Moretti (2009).

14 The online Appendix contains a picture of the experimental setup during the real-effort task.
} 
we conducted an extensive survey and qualitative interviews. The payments were made at the end of the data collection.

In total, there were 25 sessions. The sharecropping, fixed rent and ownership treatments were each assigned six times; the fixed wage treatment was assigned seven times. Each session had 20 peasants. The enumerators carefully explained the real-effort experiment, showed how to carry out the task and how peasants would be paid. Peasants then answered control questions to demonstrate that they understood the task. Explaining and conducting the real-effort experiment usually took more than 60 minutes. The complete experimental session took one-half of the day. In addition to a 20 Birr show-up fee, the peasants earned, on average, 20 Birr in the fixed wage treatment, 26.4 Birr in the sharecropping treatment, 39.8 Birr in the fixed rent treatment, and 58.4 Birr in the ownership treatment.

\section{Results}

Our sample consists of 500 farmers. Table 2 summarizes their demographic characteristics and performance in the real-effort task. Ninety percent of them were male and their average age was 43.1 years. The majority of subjects were literate (56 percent), married (87 percent) and organized in social or political institutions (73 percent). Forty-five percent of our subjects were real-life sharecroppers $^{15}$ and 60 percent came from the Amhara region. Unfortunately, despite random assignment of treatment, our sample is not fully balanced with respect to gender, literacy level of household head, and family size. ${ }^{16}$ To study the impact of our contract treatments on real-effort output, we therefore include a broad range of controls in our regressions. The average outputs in our four treatments were as follows: $138 \mathrm{~g}$ in the fixed wage treatment, $131 \mathrm{~g}$ in the sharecropping treatment, $149 \mathrm{~g}$ in the fixed rent treatment, and $146 \mathrm{~g}$ in the ownership treatment.

Table 3 shows the results of an OLS regression. The sharecropping treatment is our reference category. We include controls for subjects' personal characteristics (controls A), controls for subjects' household characteristics (controls B), controls for subjects' agricultural production characteristics (controls C), and controls for subjects' participation in various government programmes (controls D) in our regression analysis. ${ }^{17}$ Standard errors are clustered at the session level to account for correlation of error terms within each session.

First, we observe that the output in the fixed rent treatment is significantly larger than in the sharecropping treatment; the point estimate is 12.5 percent without controls (Table 3, column (1)) and 11.9 percent with all controls (Table 3,

15 This means that the subject works on at least one sharecropped plot (he may also rent or own land).

16 Table 2 and Table A1 in the Appendix present balancing checks for all control variables.

17 See the Appendix for the variable definitions. 
Table 2. Descriptive statistics and balance of sample

\begin{tabular}{|c|c|c|c|c|c|c|}
\hline & $\begin{array}{l}\text { Fixed } \\
\text { wage }\end{array}$ & $\begin{array}{l}\text { Share- } \\
\text { cropping }\end{array}$ & $\begin{array}{c}\text { Fixed } \\
\text { rent }\end{array}$ & $\begin{array}{l}\text { Owner- } \\
\text { ship }\end{array}$ & Total & $\begin{array}{l}P \text {-value } \\
\text { of } F \text {-test }\end{array}$ \\
\hline & (1) & (2) & (3) & (4) & (5) & (6) \\
\hline \multicolumn{7}{|l|}{ Session information } \\
\hline Number of sessions & 7 & 6 & 6 & 6 & 25 & \\
\hline Number of participants & 140 & 120 & 120 & 120 & 500 & \\
\hline \multicolumn{7}{|l|}{ Participant characteristics } \\
\hline $\begin{array}{l}\text { Gender } \\
\qquad(0=\text { male }, 1=\text { female })\end{array}$ & $\begin{array}{c}0.10 \\
(0.30)\end{array}$ & $\begin{array}{c}0.05 \\
(0.22)\end{array}$ & $\begin{array}{c}0.14 \\
(0.35)\end{array}$ & $\begin{array}{c}0.12 \\
(0.32)\end{array}$ & $\begin{array}{c}0.10 \\
(0.30)\end{array}$ & 0.094 \\
\hline Age (in years) & $\begin{array}{c}41.94 \\
(10.36)\end{array}$ & $\begin{array}{c}44.03 \\
(10.86)\end{array}$ & $\begin{array}{l}44.80 \\
(10.56)\end{array}$ & $\begin{array}{c}41.81 \\
(11.10)\end{array}$ & $\begin{array}{l}43.10 \\
(10.76)\end{array}$ & 0.102 \\
\hline $\begin{array}{l}\text { Member social-political } \\
\quad \text { organization }(1=\text { yes, } 0=\text { no) }\end{array}$ & $\begin{array}{c}0.71 \\
(0.46)\end{array}$ & $\begin{array}{c}0.77 \\
(0.42)\end{array}$ & $\begin{array}{c}0.73 \\
(0.45)\end{array}$ & $\begin{array}{c}0.71 \\
(0.46)\end{array}$ & $\begin{array}{c}0.73 \\
(0.45)\end{array}$ & 0.681 \\
\hline $\begin{array}{l}\text { Literate household head } \\
\qquad(1=\text { yes, } 0=\text { no })\end{array}$ & $\begin{array}{c}0.58 \\
(0.49)\end{array}$ & $\begin{array}{c}0.65 \\
(0.48)\end{array}$ & $\begin{array}{c}0.46 \\
(0.50)\end{array}$ & $\begin{array}{c}0.53 \\
(0.50)\end{array}$ & $\begin{array}{c}0.56 \\
(0.50)\end{array}$ & 0.063 \\
\hline Married $(1=$ yes, $0=$ no $)$ & $\begin{array}{c}0.84 \\
(0.37)\end{array}$ & $\begin{array}{c}0.92 \\
(0.28)\end{array}$ & $\begin{array}{c}0.86 \\
(0.35)\end{array}$ & $\begin{array}{c}0.87 \\
(0.33)\end{array}$ & $\begin{array}{c}0.87 \\
(0.34)\end{array}$ & 0.248 \\
\hline $\begin{array}{l}\text { Ethnic minority group } \\
\qquad(1=\text { yes, } 0=\text { no })\end{array}$ & $\begin{array}{c}0.53 \\
(0.50)\end{array}$ & $\begin{array}{c}0.57 \\
(0.50)\end{array}$ & $\begin{array}{c}0.69 \\
(0.46)\end{array}$ & $\begin{array}{c}0.83 \\
(0.38)\end{array}$ & $\begin{array}{c}0.65 \\
(0.48)\end{array}$ & 0.539 \\
\hline $\begin{array}{l}\text { Number of family } \\
\text { members }\end{array}$ & $\begin{array}{l}5.78 \\
(1.94)\end{array}$ & $\begin{array}{c}6.37 \\
(2.31)\end{array}$ & $\begin{array}{l}5.95 \\
(1.94)\end{array}$ & $\begin{array}{l}5.49 \\
(1.68)\end{array}$ & $\begin{array}{l}5.89 \\
(2.00)\end{array}$ & 0.053 \\
\hline Real-life sharecropper & $\begin{array}{c}0.46 \\
(0.50)\end{array}$ & $\begin{array}{c}0.45 \\
(0.50)\end{array}$ & $\begin{array}{c}0.39 \\
(0.49)\end{array}$ & $\begin{array}{c}0.51 \\
(0.50)\end{array}$ & $\begin{array}{c}0.45 \\
(0.50)\end{array}$ & 0.640 \\
\hline Amhara region $(1=$ yes, $0=$ no $)$ & $\begin{array}{c}0.58 \\
(0.50)\end{array}$ & $\begin{array}{c}0.33 \\
(0.47)\end{array}$ & $\begin{array}{c}0.66 \\
(0.47)\end{array}$ & $\begin{array}{c}0.83 \\
(0.38)\end{array}$ & $\begin{array}{c}0.60 \\
(0.49)\end{array}$ & 0.277 \\
\hline \multicolumn{7}{|l|}{ Output measures - All participants } \\
\hline Output in grams & $\begin{array}{l}137.89 \\
(28.87)\end{array}$ & $\begin{array}{l}131.34 \\
(23.98)\end{array}$ & $\begin{array}{l}149.44 \\
(24.56)\end{array}$ & $\begin{array}{l}146.07 \\
(26.14)\end{array}$ & $\begin{array}{l}141.05 \\
(26.92)\end{array}$ & \\
\hline ln of output in grams & $\begin{array}{c}4.90 \\
(0.23)\end{array}$ & $\begin{array}{c}4.86 \\
(0.18)\end{array}$ & $\begin{array}{c}4.99 \\
(0.17)\end{array}$ & $\begin{array}{c}4.97 \\
(0.18)\end{array}$ & $\begin{array}{c}4.93 \\
(0.20)\end{array}$ & \\
\hline Payout received & $\begin{array}{l}21.09 \\
(3.04)\end{array}$ & $\begin{array}{l}25.16 \\
(4.90)\end{array}$ & $\begin{array}{l}39.78 \\
(9.82)\end{array}$ & $\begin{array}{c}58.43 \\
(10.46)\end{array}$ & $\begin{array}{c}35.51 \\
(16.50)\end{array}$ & \\
\hline \multicolumn{7}{|c|}{ Output measures - Real-life non-sharecroppers (272 participants) } \\
\hline Output in grams & $\begin{array}{l}138.87 \\
(32.53)\end{array}$ & $\begin{array}{l}135.47 \\
(24.91)\end{array}$ & $\begin{array}{l}146.83 \\
(24.19)\end{array}$ & $\begin{array}{l}148.38 \\
(28.84)\end{array}$ & $\begin{array}{l}142.18 \\
(28.25)\end{array}$ & \\
\hline
\end{tabular}


Table 2. (Continued)

\begin{tabular}{lcccccc}
\hline & $\begin{array}{c}\text { Fixed } \\
\text { wage }\end{array}$ & $\begin{array}{c}\text { Share- } \\
\text { cropping }\end{array}$ & $\begin{array}{c}\text { Fixed } \\
\text { rent }\end{array}$ & $\begin{array}{c}\text { Owner- } \\
\text { ship }\end{array}$ & Total & $\begin{array}{c}P \text {-value } \\
\text { of } \boldsymbol{F} \text {-test }\end{array}$ \\
\cline { 2 - 7 } & $\mathbf{( 1 )}$ & $\mathbf{( 2 )}$ & $\mathbf{( 3 )}$ & $\mathbf{( 4 )}$ & $\mathbf{( 5 )}$ & $\mathbf{( 6 )}$ \\
\hline ln of output in grams & 4.90 & 4.89 & 4.98 & 4.98 & 4.94 & \\
& $(0.26)$ & $(0.18)$ & $(0.17)$ & $(0.20)$ & $(0.21)$ & \\
Output measures - Real-life sharecroppers $(227$ participants) & & & & \\
Output in grams & 136.72 & 126.30 & 153.35 & 144.26 & 139.78 \\
& $(24.02)$ & $(21.98)$ & $(24.83)$ & $(23.41)$ & $(25.27)$ \\
ln of output in grams & 4.90 & 4.82 & 5.02 & 4.96 & 4.92 \\
& $(0.18)$ & $(0.18)$ & $(0.16)$ & $(0.16)$ & $(0.18)$ \\
\hline
\end{tabular}

Notes: Means and standard deviations in parentheses. Standard errors are clustered at the session level for the $P$-value of the $F$-test in column 6 . Significance levels at ${ }^{*} P<0.10,{ }^{* *} P<0.05,{ }^{* * *} P<0.01$.

Table 3. Contract treatments and real-effort output

\begin{tabular}{lccccc}
\hline & \multicolumn{5}{c}{ ln of real-effort output } \\
\cline { 2 - 6 } & $\mathbf{( 1 )}$ & $\mathbf{( 2 )}$ & $\mathbf{( 3 )}$ & $\mathbf{( 4 )}$ & $\mathbf{( 5 )}$ \\
\hline Fixed wage & 0.029 & 0.023 & 0.016 & 0.013 & 0.013 \\
& $(0.057)$ & $(0.055)$ & $(0.056)$ & $(0.053)$ & $(0.052)$ \\
Fixed rent & $0.125^{* *}$ & $0.121^{* *}$ & $0.124^{* *}$ & $0.121^{* *}$ & $0.119^{* *}$ \\
& $(0.051)$ & $(0.055)$ & $(0.054)$ & $(0.053)$ & $(0.052)$ \\
Ownership & $0.100^{*}$ & $0.089^{*}$ & $0.089^{*}$ & $0.086^{*}$ & $0.083^{* *}$ \\
& $(0.050)$ & $(0.044)$ & $(0.045)$ & $(0.042)$ & $(0.040)$ \\
Sharecropping & $4.868^{* * *}$ & $4.810^{* * *}$ & $4.803^{* * *}$ & $4.798^{* * *}$ & $4.791^{* * *}$ \\
$\quad$ constant) & $(0.028)$ & $(0.132)$ & $(0.163)$ & $(0.211)$ & $(0.218)$ \\
Controls A & No & Yes & Yes & Yes & Yes \\
Controls B & No & No & Yes & Yes & Yes \\
Controls C & No & No & No & Yes & Yes \\
Controls D & No & No & No & No & Yes \\
$R^{2}$ & 0.065 & 0.220 & 0.193 & 0.213 & 0.220 \\
Observations & 500 & 497 & 469 & 469 & 469 \\
\hline
\end{tabular}

Notes: Dependent variable is $\ln ($ real-effort output in grams). OLS regression with control variables as indicated. Results are robust to using weighted OLS regressions to account for unequal selection probabilities in the sampling procedure, and largely robust to using wild bootstrapped clustered standard errors as shown in the online Appendix, Tables A5 and A8. Standard errors are in parentheses and clustered at the session level. Significance levels at ${ }^{*} P<0.10,{ }^{* *} P<0.05,{ }^{* * *} P<0.01$. 
column (5)). ${ }^{18}$ Also, output in the sharecropping treatment is significantly lower than in the ownership treatment; the point estimate is 10.0 percent without controls and 8.3 percent with all controls. Both findings clearly point towards an incentive effect of sharecropping in the expected direction.

Second, we do not observe any significant difference between output in the fixed wage treatment and output in the sharecropping treatment (our reference category). The minimum detectable effect size by which we could reject the null hypothesis of no effect under the alternative hypothesis of there being an effect is 16.0 percent which implies that we can rule out that the difference between these two treatments is larger than this. ${ }^{19}$ This is surprising, since the empirical contract theory literature typically reports a large and positive increase in output when incentives change from fixed wages to piece rates. We summarize our results.

Result 1. The incentive effect of sharecropping in our real-effort task amounts to 11.9 percent.

Result 2. The sharecropping output cannot be statistically distinguished from the fixed wage output.

Result 2 is difficult to reconcile from an incentive perspective. One possible explanation is that the piece rate in our sharecropping treatment was too low to induce more effort than in the absence of any incentives. However, recall that we set piece rates so that peasants could earn their daily expenditure within 15 minutes.

An alternative explanation is that the framing of the treatment as a sharecropping contract induced relatively low effort in this treatment. Historically, sharecropping often has been perceived as an exploitative arrangement between a relatively rich owner of land and a poorer worker. ${ }^{20}$ If sharecropping is associated with negative emotions - such as unfairness or exploitation - real-life sharecroppers may be particularly receptive to our sharecropping frame in the experiment. Thus, they may be more likely to react negatively by under-providing effort.

18 Results are robust to applying sample weights in the regression and robust to accounting for small number of clusters using robust wild bootstrapped standard errors (see Cameron et al., 2008) when covariates A and B are included.

19 Calculations of the minimum detectable effect size are based on the standard error of 0.057 of the coefficient for sharecropping when all controls are included (Table 2, column (5)) multiplied by $1.96+0.84=2.8$; multiplying by 1.96 would allow us to reject the null hypothesis of a zero effect for an alpha $=0.05$, and we add the $t$-value for (1-power), which is 0.84 for power set to 0.8 , to reject the null hypothesis if the alternative hypothesis of there being an effect is true. It is important to add the second part since the first on its own could also be driven by a false positive, that is, a true null hypothesis that is falsely rejected.

${ }^{20}$ Moreover, sharecropping is often regarded as creating a vicious cycle, where the tenant over time gets trapped in debt as he must purchase overpriced supplies directly from the landlord; see, for example, Delville et al. (2002). 
We test this alternative explanation and analyze how output in the experiment differs across real-life sharecroppers and non-sharecroppers. ${ }^{21}$ Table 2 provides the descriptive statistics. Both groups produce roughly the same output in the fixed wage treatment (139 and $137 \mathrm{~g}$, respectively). However, in the sharecropping treatment, real-life sharecroppers produce only $126 \mathrm{~g}$ of output, while non-sharecroppers produce $135 \mathrm{~g}^{22}$ We further examine the behaviour of the real-life sharecroppers in our sample by extending our basic regressions. We include a binary indicator for real-life sharecroppers and a binary indicator for the region of Amhara (where a controversial land reform took place that we discuss in the next section). Furthermore, we include interaction terms for sharecropping treatment, real-life sharecropping, and Amhara. Table 4 displays the results.

We find that real-life sharecroppers from Amhara produce significantly less output in the sharecropping treatment than their counterparts from the other regions (Oromia). The joint effect of being assigned to the sharecropping treatment, being a real-life sharecropper, and being from the Amhara region has a negative effect on output of 12.4 percent $(P=0.001$ in Table 4 , column (5)). This result is robust in order of magnitude and significance with different sets of controls in the regression.

Given that Amhara is a regional dummy, it could, in principle, pick up any aggregate effect that systematically varies between Amhara and Oromia. These could be caused by differences in diligence or attitudes towards work on the part of people in the two regions, also captured by the regional dummy. However, if this were the case, we should observe a lower output under the other contract treatments as well. As a robustness check, we repeat the analyses with the fixed rent and ownership treatment instead of the sharecropping treatment. ${ }^{23}$ We find no difference for real-life sharecroppers in Amhara for these contract treatments.

Next, we restrict our sample to sessions in Amhara, see Table 5. We observe that real-life sharecroppers in this region produce 12.9 percent less output in the sharecropping treatment than in the fixed wage treatment (Table 5, column (5)). Real-life sharecroppers in Oromia produce 5.0 percent less output in the sharecropping treatment than in the fixed wage treatment. This difference, however, is not significant. ${ }^{24}$ We summarize these results.

21 A subject in our experiment is classified as real-life sharecropper if he/she works on at least one sharecropped plot. Real-life sharecroppers are different from non-sharecroppers in real-life. We are not claiming causal interpretation of our results but suggest alternative interpretations of the results based on these heterogeneous treatment effects.

${ }^{22}$ In principle, this finding could also be explained by the fact that real-life sharecroppers have less need for cash than non-sharecroppers since they do not have to buy investments. However, we find differences in behaviour only in the sharecropping treatment and not in the fixed rent or ownership treatment. Hence, different needs for cash cannot explain our results. In addition, since money is fungible, all participants in our sample of poor peasants are likely to need cash.

23 See Tables A2 and A3 in the online Appendix.

24 See Table A4 in the online Appendix. Calculations for real-life sharecroppers vs. non-sharecroppers in Oromia based on the standard error of the estimated coefficient and a power of 0.8 for non-sharecroppers in Oromia show a minimum detectable effect size of 15.7 percent. 
Table 4. Contract treatments and real-effort output, by real-life sharecropper

\begin{tabular}{|c|c|c|c|c|c|}
\hline & \multicolumn{5}{|c|}{ ln of real-effort output } \\
\hline & (1) & (2) & (3) & (4) & (5) \\
\hline Sharecropping & $\begin{array}{l}-0.003 \\
(0.066)\end{array}$ & $\begin{array}{c}0.005 \\
(0.065)\end{array}$ & $\begin{array}{c}0.014 \\
(0.065)\end{array}$ & $\begin{array}{c}0.004 \\
(0.064)\end{array}$ & $\begin{array}{c}0.006 \\
(0.064)\end{array}$ \\
\hline Fixed rent & $\begin{array}{c}0.086 \\
(0.064)\end{array}$ & $\begin{array}{c}0.098 \\
(0.065)\end{array}$ & $\begin{array}{c}0.109 \\
(0.067)\end{array}$ & $\begin{array}{l}0.112^{*} \\
(0.064)\end{array}$ & $\begin{array}{l}0.111^{*} \\
(0.064)\end{array}$ \\
\hline Ownership & $\begin{array}{c}0.056 \\
(0.064)\end{array}$ & $\begin{array}{c}0.065 \\
(0.059)\end{array}$ & $\begin{array}{c}0.074 \\
(0.062)\end{array}$ & $\begin{array}{c}0.076 \\
(0.056)\end{array}$ & $\begin{array}{c}0.073 \\
(0.056)\end{array}$ \\
\hline Real-life sharecropper & $\begin{array}{c}-0.004 \\
(0.026)\end{array}$ & $\begin{array}{c}0.003 \\
(0.024)\end{array}$ & $\begin{array}{c}0.008 \\
(0.025)\end{array}$ & $\begin{array}{c}0.000 \\
(0.024)\end{array}$ & $\begin{array}{c}0.001 \\
(0.025)\end{array}$ \\
\hline Amhara & $\begin{array}{c}0.041 \\
(0.050)\end{array}$ & $\begin{array}{c}0.003 \\
(0.064)\end{array}$ & $\begin{array}{r}-0.006 \\
(0.066)\end{array}$ & $\begin{array}{r}-0.028 \\
(0.083)\end{array}$ & $\begin{array}{r}-0.028 \\
(0.083)\end{array}$ \\
\hline Sharecropping $\times$ Real-life sharecropper & $\begin{array}{c}0.004 \\
(0.029)\end{array}$ & $\begin{array}{r}-0.028 \\
(0.034)\end{array}$ & $\begin{array}{r}-0.045 \\
(0.035)\end{array}$ & $\begin{array}{r}-0.028 \\
(0.041)\end{array}$ & $\begin{array}{r}-0.028 \\
(0.042)\end{array}$ \\
\hline Sharecropping $\times$ Amhara & $\begin{array}{l}-0.007 \\
(0.066)\end{array}$ & $\begin{array}{c}0.004 \\
(0.088)\end{array}$ & $\begin{array}{c}0.017 \\
(0.092)\end{array}$ & $\begin{array}{c}0.048 \\
(0.094)\end{array}$ & $\begin{array}{c}0.040 \\
(0.097)\end{array}$ \\
\hline $\begin{array}{l}\text { Sharecropping } \times \text { Real-life } \\
\text { sharecropper } \times \text { Amhara }\end{array}$ & $\begin{array}{l}-0.127^{* * * *} \\
(0.026)\end{array}$ & $\begin{array}{l}-0.092^{* * *} \\
(0.029)\end{array}$ & $\begin{array}{l}-0.085^{* * *} \\
(0.027)\end{array}$ & $\begin{array}{c}-0.123^{* * *} \\
(0.033)\end{array}$ & $\begin{array}{c}-0.115^{* * * x} \\
(0.037)\end{array}$ \\
\hline Fixed wage (Constant) & $\begin{array}{l}4.881^{* * *} \\
(0.058)\end{array}$ & $\begin{array}{l}4.840^{* * *} \\
(0.133)\end{array}$ & $\begin{array}{l}4.807^{* * *} \\
(0.166)\end{array}$ & $\begin{array}{l}4.799^{* * *} \\
(0.209)\end{array}$ & $\begin{array}{l}4.792^{* * *} \\
(0.212)\end{array}$ \\
\hline Controls A & No & Yes & Yes & Yes & Yes \\
\hline Controls B & No & No & Yes & Yes & Yes \\
\hline Controls C & No & No & No & Yes & Yes \\
\hline Controls D & No & No & No & No & Yes \\
\hline $\begin{array}{l}\text { Joint effect of sharecropping, real- } \\
\text { life sharecropper, Amhara, and all } \\
\text { interaction terms }\end{array}$ & -0.096 & -0.105 & -0.097 & -0.127 & -0.124 \\
\hline$P$-value of joint $F$-test & 0.000 & 0.002 & 0.000 & 0.000 & 0.001 \\
\hline$R^{2}$ & 0.085 & 0.232 & 0.207 & 0.232 & 0.237 \\
\hline Observations & 499 & 497 & 469 & 469 & 469 \\
\hline
\end{tabular}

Notes: Dependent variable is $\ln$ (real-effort output in grams). OLS regression with control variables as indicated. Results are robust to using weighted OLS regressions to account for unequal selection probabilities in the sampling procedure, and to using wild bootstrapped clustered standard errors as shown in the online Appendix, Tables A6 and A9. Standard errors are in parentheses and clustered at the session level. Significance levels at ${ }^{*}<0.10,{ }^{* *} P<0.05,{ }^{* * *} P<0.01$. 
Table 5. Contract treatments and real-effort output, by real-life sharecropper, Amhara only

\begin{tabular}{lccccc}
\hline & \multicolumn{5}{c}{ ln of real-effort output } \\
\cline { 2 - 6 } & $\mathbf{( 1 )}$ & $\mathbf{( 2 )}$ & $\mathbf{( 3 )}$ & $\mathbf{( 4 )}$ & $\mathbf{( 5 )}$ \\
\hline Sharecropping & -0.031 & -0.017 & 0.003 & 0.023 & 0.016 \\
& $(0.082)$ & $(0.103)$ & $(0.116)$ & $(0.113)$ & $(0.120)$ \\
Fixed rent & 0.062 & 0.078 & 0.090 & 0.089 & 0.086 \\
& $(0.101)$ & $(0.101)$ & $(0.104)$ & $(0.102)$ & $(0.107)$ \\
Ownership & 0.057 & 0.066 & 0.076 & 0.068 & 0.064 \\
& $(0.089)$ & $(0.080)$ & $(0.086)$ & $(0.073)$ & $(0.076)$ \\
Real-life sharecropper & -0.029 & -0.005 & 0.005 & -0.011 & -0.016 \\
& $(0.029)$ & $(0.029)$ & $(0.029)$ & $(0.028)$ & $(0.032)$ \\
Sharecropping $\times$ Real-life & $-0.099^{* *}$ & $-0.109^{* *}$ & $-0.121^{* *}$ & $-0.144^{* *}$ & $-0.129^{* *}$ \\
sharecropper & $(0.037)$ & $(0.044)$ & $(0.044)$ & $(0.054)$ & $(0.060)$ \\
Fixed wage (Constant) & $4.943^{* * *}$ & $4.621^{* * *}$ & $4.605^{* * *}$ & $4.543^{* * *}$ & $4.555^{* * *}$ \\
& $(0.077)$ & $(0.229)$ & $(0.319)$ & $(0.336)$ & $(0.329)$ \\
Controls A & No & Yes & Yes & Yes & Yes \\
Controls B & No & No & Yes & Yes & Yes \\
Controls C & No & No & No & Yes & Yes \\
Controls D & No & No & No & No & Yes \\
Joint effect of & -0.159 & -0.131 & -0.113 & -0.132 & -0.129 \\
sharecropping, real-life & & & & & \\
sharecropper, and all & & & & & \\
interaction terms & & & & & \\
P-value of joint F-test & 0.000 & 0.030 & 0.004 & 0.007 & 0.026 \\
$R^{2}$ & 0.092 & 0.285 & 0.260 & 0.301 & 0.310 \\
Observations & 299 & 298 & 280 & 280 & 280 \\
\hline
\end{tabular}

Notes: Dependent variable is $\ln$ (real-effort output in grams). OLS regression with control variables as indicated. Results are robust to using weighted OLS regressions to account for unequal selection probabilities in the sampling procedure, and to using wild bootstrapped clustered standard errors as shown in the online Appendix, Tables A7 and A10. Standard errors are in parentheses and clustered at the session level. Significance levels at ${ }^{*} P<0.10,{ }^{* *} P<0.05,{ }^{* * *} P<0.01$.

Result 3. In the sharecropping treatment, real-life sharecroppers produce less output than non-sharecroppers. This effect is especially pronounced for real-life sharecroppers in Amhara. They produce around 12 percent less output in the sharecropping treatment than in the fixed wage treatment. In all other treatments, there is no significant difference between the average outputs of real-life sharecroppers and non-sharecroppers. 


\section{Interpretation}

The regional variation and the behavioural differences between real-life sharecroppers and non-sharecroppers demand an explanation. Since this result was unexpected, the design of the experiment does not allow us to draw a conclusive answer from the data. However, there are a number of indications that render fairness concerns as a reasonable explanation for the observed patterns. The sharecropping treatment has a framing effect on subjects, in particular on those who are real-life sharecroppers. This framing reminds the subjects of the unfair profit sharing they are exposed to in real life. In Amhara, it also reminds them of the unfair distribution of land. Both effects reduce their motivation, so that we see a significant behavioural difference between sharecroppers and non-sharecroppers under the sharecropping treatment (but not under the other treatments), and this effect is especially pronounced in Amhara. ${ }^{25}$ To substantiate this view, we analyze the qualitative interviews that we conducted after the data collection, and review historical accounts of the land reform that took place in Amhara in 1997.

\subsection{Feedback from interviews}

We draw on qualitative interviews which were part of the survey data collected after the experiment. The enumerators asked subjects the following two questions: What are the advantages and disadvantages of the different land arrangements in general? What are the reasons you chose your land arrangements? After each interview, the enumerators summarized the main statements in two or three sentences.

The peasants named the following motives for their contract choices in the land market: risk sharing, excess labour for the given land holdings, no real choice between fixed rent and sharecropping contracts (landlords impose sharecropping on tenants), and a land shortage due to an unequal land distribution. A number of peasants complained about the lack of cost sharing between landlord and tenant. ${ }^{26}$ A typical farmer statement is as follows:

'Sharecropping is the better arrangement for the landowner. He gets half of the output without contributing work or other inputs to the crop production process'. (A Farmer from the Kebele Addisena Guilt)

25 Also the rental contract may trigger thoughts of the unequal land distribution. However, under the rental contract, subjects earn their full marginal returns. So they do not have to share their total income and fairness concerns are less of an issue (note also that under the rental contract, the more output subjects produce, the smaller is the income share they have to pay).

26 This point is also made in Deininger et al. (2011), who find that sharecropped plots yield 16-25 percent less output than owned plots cultivated by the same households. The inefficiency disappears for sharecropping contracts where the input costs are shared. This, however, is very uncommon in Ethiopia (in the sample of Deininger et al., 2011, only 12.1 percent of all sharecropping contracts have a cost-sharing component). 
We found two peculiar patterns in how peasants answered our two questions. First, sharecroppers refer more commonly to land shortage as a reason for going into the land market. Second, the peasants in Amhara more commonly refer to a land shortage due to the land redistribution from 1997 (interestingly, these answers are most densely clustered among those sharecroppers who were randomly assigned to the sharecropping treatment). We, therefore, review the historical accounts of this land reform, and then return to the interviews.

\subsection{The 1997 Amhara Land Reform}

In 1997, a land redistribution took place in the southern half of Amhara. ${ }^{27}$ Its official intent was to achieve a more equal land distribution and to punish those individuals who had held public office during the preceding communist regime (the Därg). This group of people was labelled 'birokrasi' and usually consisted of respected and relatively educated individuals.

In the first phase of the land reform, households and land holdings were registered. In the second phase, land was measured, confiscated, and redistributed. The first phase was carried out in secret and without public debate. The absence of any appeal system additionally undermined the legitimacy of the land reform. There were plenty of opportunities to game the system, for example, by registering several household members as belonging to different households. Overall, the registration was 'quick, but it was neither transparent nor democratic, and it produced some most arbitrary results' (Ege, 2002, p. 80).

In the second phase, officials measured the land and thereby became accessible to peasants. It, therefore, was possible to change the outcome of the land reform by secret arrangements with officials (a record that entitles the peasant to larger land holdings in exchange for money, food, and submissive behaviour). The birokrasi had to enter into secret negotiations or else they would lose a large part of their wealth. Since the discrimination against the birokrasi had no support from below, officials were quite open to these negotiations. Kinship and friendship had a significant influence on the outcomes. Ege (2002, p. 83) writes that '[there] is even reason to believe that in such a chaotic situation as the 1997 land redistribution, the unscrupulous birokrasi fared better than the honest ones, certainly a design weakness of the reform on its own terms'. Peasants reported 'secret deals, corruption, misdeeds against individual households, and not the least, land grabbing by the distributors and their friends' (Ege, 2002, p. 84). The land reform produced winners and some great losers who ended up with almost no land. The predominant view of the land reform, even among those who supported it, is that it was quite unfair. Ege (2002, p. 71) summarizes the reform as follows: '[...] it was a very dramatic redistribution that ruined many households, uprooted the existing land tenure system without replacing it with a well-defined new system, and created a new state-peasant relationship'.

27 The contents of this section are based on Ege $(1997,2002)$.

(c) 2018 The Authors

Economics of Transition (c) 2018 The European Bank for Reconstruction and Development 
The land reform was mentioned in a number of interviews in Amhara (although we did not ask any question in this direction), especially by real-life sharecroppers. In particular, those who now have land and offer it on the land market are accused of corrupt behaviour. The following quotes express this view:

'Those who are renting-in and sharecropping-in approach (corrupt) the local officials and try to secure certificates for these parcels which do not belong to them'. (A Farmer from the Kebele Kimbaba)

'Through sharecropping land arrangement the owner of the land will be the one who [is] benefited. Often [the] land owner benefits from corrupt officials during land redistribution'. (A Farmer from the Kebele Kebi)

'Today those farmers sharecrop who did not pay officials during land redistribution'. (A Farmer from the Kebele Sebat Amit)

\section{Conclusion}

In this paper, we provided experimental evidence for an incentive effect of sharecropping. In a representative sample of real-life tenants, sharecropping output was about 12 percent smaller than the output under fixed rent contracts. However, we also found that the output gap between contracts with full and partial marginal returns cannot be attributed to incentives alone. Real-life sharecroppers produced significantly less than non-sharecroppers. In Amhara, where a controversial land reform took place, real-life sharecroppers even produced 12 percent less in the sharecropping treatment than in the fixed wage treatment. We therefore conjecture that the perceived fairness of profit sharing and the historical context matter for the contractual performance of sharecropping.

A possible route ahead is to use observational data and compare input intensities for farmers who both sharecrop and own plots, following the standard fixed-effects approach. Our results suggest that the incentive effect of sharecropping is larger in Amhara than in Oromia. To confirm this, we would need observational data on agricultural households in Amhara and Oromia that contains data on agricultural inputs dis-aggregated by plot and contractual arrangement (to indicate whether a particular plot was sharecropped or rented in the land market). Unfortunately, we were not able to find such a dataset, despite the availability of household survey data for Ethiopia. ${ }^{28}$

\footnotetext{
28 The Agricultural Sample Surveys and the Ethiopia Rural Socioeconomic Survey of 2011 have data on agricultural inputs by plot for households in Amhara and Oromia, but they do not distinguish between plots that are rented and those that are sharecropped in the land market. The Ethiopian Rural Household Surveys of 1989, 1994/95, 1997, 1999, 2004 and 2009 distinguish between rented plots and sharecropped plots for households in Amhara and Oromia, but they do not collect data on agricultural (labour) inputs by plot.
} 
We hope that future data collection efforts will make it possible to test whether there is evidence for the context dependence of incentives.

Improving access to land through land markets is widely held to be a key to fighting extreme poverty in agrarian economies in sub-Saharan Africa and elsewhere. Land markets are believed to help transfer land to the most efficient producers and support the occupational transformation (The World Bank, 2008). We think that our findings have some policy relevance for two reasons. First, efficiency gains from contracting land and labour in markets may be smaller than expected if land arrangements between the contracting parties are politically, socially, and historically charged in a way that affects productivity through fairness concerns. Second, the relationship between farm size and productivity has been controversial for decades. Proponents of land-rich farms argue that there are increasing returns to scale in farm size (due to lumpy inputs and better access to credit), while opponents argue that hiring labour or sharecropping-out land is less productive than family labour (receiving full marginal returns). If fairness concerns matter and big farms are the result of a redistribution process that is perceived as unfair, big farms may lose productivity vis-á-vis small farms.

\section{References}

Ackerberg, D. and Botticini, M. (2002). 'Endogenous matching and the empirical determinants of contract form', Journal of Political Economy, 110(3), pp. 564-591.

Bandiera, O., Barankay, I. and Rasul, I. (2005). 'Social preferences and the response to incentives: Evidence from personnel data', Quarterly Journal of Economics, 120(3), pp. 917-962.

Bell, C. (1977). 'Alternative theories of sharecropping: Some tests using evidence from Northeast India', The Journal of Development Studies, 13(4), pp. 317-346.

Benjamin, D. J., Choi, J. J. and Strickland, A. J. (2010). 'Social identity and preferences', American Economic Review, 100(4), pp. 1913-1928.

Binswanger, H. and Rosenzweig, M. (1986). 'Behavioural and material determinants of production relations in agriculture', Journal of Development Studies, 22(3), pp. 503-539.

Blanes-i-Vidal, J. and Nossol, M. (2011). 'Tournaments without prizes: Evidence from personnel records', Management Science, 57(10), pp. 1721-1736.

Breza, E., Kaur, S. and Shamdasani, Y. (forthcoming). 'The morale effects of pay inequality', Quarterly Journal of Economics.

Burchardi, K., Gulesci, S., Lerva, B. and Sulaiman, M. (2017). 'Moral hazard: Experimental evidence from tenancy contracts', Working Paper, Stockholm: IIES, Stockholm University.

Cameron, A. C., Gelbach, J. and Miller, D. (2008). 'Bootstrap-based improvements for inference with clustered errors', Review of Economics and Statistics, 90(3), pp. 414-427.

Charness, G. and Kuhn, P. (2011). 'Lab labor: What can labor economists learn from the lab?' Handbook of Labor Economics, 4A, pp. 229-330.

Cohn, A., Fehr, E. and Goette, L. (2015). 'Fair wages and effort provision: Combining evidence from a choice experiment and a field experiment', Management Science, 61(8), pp. 17771794. 
Czura, K. (2015). 'Pay, peek, punish? Repayment, information acquisition and punishment in a microcredit lab-in-the-field experiment', Journal of Development Economics, 117, pp. 119-133.

Deininger, K., Ali, D. A. and Alemu, T. (2008). 'Assessing the functioning of land rental markets in Ethiopia', Economic Development and Cultural Change, 57(1), pp. 67-100.

Deininger, K., Ali, D. A. and Alemu, T. (2011). 'Impacts of land certification on tenure security, investment, and land market participation: Evidence from Ethiopia', Land Economics, 87 (2), pp. 312-334.

Deininger, K., Ali, D. A. and Alemu, T. (2013). 'Productivity effects of land rental market operation in Ethiopia: Evidence from a matched tenant-landlord sample', Applied Economics, 45(25), pp. 3531-3551.

Delville, P. L., Toulmin, C., Colin, J.-P. and Chauveau, J.-P. (2002). Negotiating Access to Land in West Africa: A Synthesis of Findings from Research on Derived Rights to Land, London: International Institute for Environment and Development.

Ege, S. (1997). 'The promised land: The Amhara Land Redistribution of 1997', SMU-rapport 5/ 97, Norwegian University of Science and Technology, Centre for Environment and Development, Dragvoll, Norway.

Ege, S. (2002). 'Peasant participation in land reform: The Amhara Land Redistribution of 1997', in Zewde, B. and Pausewang, S. (eds.), Ethiopia - The Challenge of Democracy from Below, Uppsala, Sweden: Nordiska Afrikainstitutet, pp. 71-86.

Englmaier, F., Roider, A. and Sunde, U. (2017). 'The role of communication of performance schemes: Evidence from a field experiment', Management Science, 63(12), pp. 4061-4080.

Falk, A. and Ichino, A. (2006). 'Clean evidence on peer effects', Journal of Labor Economics, 24 (1), pp. 39-58.

Gneezy, U. and List, J. (2006). 'Putting behavioral economics to work: Testing for gift exchange in labor markets using field experiments', Econometrica, 74(5), pp. 1365-1384.

Goldstein, M. and Udry, C. (2008). 'The profits of power: Land rights and agricultural investment in Ghana', Journal of Political Economy, 116(6), pp. 981-1022.

Hoff, K. and Pandey, P. (2006). 'Discrimination, social identity, and durable inequalities', American Economic Review, 96(2), pp. 206-211.

Hoff, K. and Pandey, P. (2014). 'Making up people - The effect of identity on performance in a modernizing society', Journal of Development Economics, 106, pp. 118-131.

Hossain, T. and List, J. (2012). 'The behavioralist visits the factory: Increasing productivity using simple framing manipulations', Management Science, 58(12), pp. 2151-2167.

Laffont, J.-J. and Matoussi, M. S. (1995). 'Moral hazard, financial constraints and sharecropping in El Oulja', Review of Economic Studies, 62(3), pp. 381-399.

Lazear, E. (2000). 'Performance pay and productivity', American Economic Review, 90(5), pp. 1346-1361.

Mas, A. and Moretti, E. (2009). 'Peers at work', American Economic Review, 99(1), pp. 112-145.

Newman, C., Tarp, F. and van den Broeck, K. (2015). 'Property rights and productivity: The case of joint land titling in Vietnam', Land Economics, 91(1), pp. 91-105.

Pender, J. and Fafchamps, M. (2006). 'Land lease markets and agricultural efficiency in Ethiopia', Journal of African Economies, 15(2), pp. 251-284.

Shaban, R. (1987). 'Testing between competing models of sharecropping', Journal of Political Economy, 95(5), pp. 893-920.

Shearer, B. (2004). 'Piece rates, fixed wages and incentives: Evidence from a field experiment', Review of Economic Studies, 71(2), pp. 513-534. 
Shi, L. (2010). 'Incentive effect of piece-rate contracts: Evidence from two small field experiments', B.E. Journal of Economic Analysis E Policy, 10(1), Topics, Article 61.

Singh, N. (1989). 'Theories of sharecropping', in Bardham, P. K. (ed.), The Economic Theory of Agrarian Institutions, (Oxford: Oxford University Press), pp. 33-72.

The World Bank (2008). 'Agriculture for development', World Development Report, Washington, DC: The World Bank.

Vollan, B., Landmann, A., Zhou, Y., Hu, B. and Herrmann-Pillath, C. (2017). 'Cooperation and authoritarian values: An experimental study in China', European Economic Review, 93, pp. $90-105$.

\section{Appendix A}

\section{A.1 Instructions to participants}

\section{A.1.1 General introduction}

Thank you all for taking the time to come today. Today's games may take 2-3 hours in the morning and 1-2 hours in the afternoon, so if you think you will not be able to stay that long let us know now. Before we begin I want to make some general comments about what we are doing here today and explain the rules that we must follow. We will be playing two games with money and also ask you a number of questions on agricultural practices.

Whatever money you win in the games will be yours to keep and take home. Mr. Kemper will be supplying the money. But you should understand that this is not Mr. Kemper's own money. It is money given to him by the University of Mannheim to use for research. This research will not be part of a development project. These games are part of a scientific research project involving many researchers like Mr. Kemper and people from many other universities.

Before we proceed any further, let me stress something that is very important. Many of you were invited here without understanding very much about what we are planning to do today. If at any time you find that this is something that you do not wish to participate in for any reason, you are free to leave regardless of whether we have started the game or not.

We will be playing two games in the morning. We are about to begin the first game. It is important that you listen as carefully as possible, because only people who understand the game will actually be able to play. We will run through some examples here while we are all together. You cannot ask questions or talk while here in the group. This is very important. Please be sure that you obey this rule, because it is possible for one person to spoil the game for everyone. If one person talks about the game while sitting in the group, we would not be able to play the game today. We also ask you to switch off your cell phones. Do not worry if you do not completely understand the game as we go through the examples here in the group. Each of you will have a chance to ask questions in private to be sure that you understand how to play. 
Before we begin the first game, I am going to pass out 20 Birr to each of you to thank-you for coming today. This money is not part of the game, it is yours to keep. You can earn more money during the games which will be paid to you at the end of the day. We will hand out a card to keep track of the money earned during the games. Please keep this card with you all the time. We will pay you the amount recorded on the card at the end of the day.

\section{A.1.2 Real-effort task}

In this game, we ask you to perform a task for which you will be paid. We will now explain the rules. We will give you a shallow bucket with beans in three different colours (white, yellow and red) and an empty bucket.

We ask you to pick as many [colour] beans as you can within the next 15 minutes from the shallow bucket and put them into the empty other bucket. The other bucket may only contain [colour] beans. Your payout depends on the task. There will neither be a payout if the other bucket contains beans with a colour other than [colour] nor if you drop beans on the floor during the task.

Interviewers hand out the shallow bucket and the other bucket to participants and demonstrate the task. They demonstrate how the task is done correctly and how it is done incorrectly. They show how many beans correspond to $100 \mathrm{~g}$. Interviewers put other buckets to the left of shallow buckets for right-handed and to the right for left-handed (ask: 'What hand do you use for working?') and ask participants not to change this order during the game. Then an interviewer reads out the compensation rules (depending on the treatment).

$(f w)$ Your payment will be determined as follows. We offer you a payment of 20 Birr for this task. For your payment it does not matter how many beans you pick. This payment is always fixed. It will be given to you at the end of the day.

For instance: You get 20 Birr for the task. If you collect $100 \mathrm{~g}$ you get 20 Birr. If you collect $120 \mathrm{~g}$ you get 20 Birr. If you collect $140 \mathrm{~g}$ you get 20 Birr.

(sh) Your payment will be determined as follows. We offer you a payment for this task which depends on how many beans you pick from the shallow bucket and put in the other bucket. The more beans there are, the higher your payment will be. We will weigh your other bucket after the task to determine the amount of your payment. However, you may not keep all the payment for yourself. You have to return to us a share of the payment for being allowed to do the task, but the rest of the payment is yours and will be given to you at the end of the day.

For instance: You get 100 Birr per $40 \mathrm{~g}$ and the share is 50 percent. If you collect $100 \mathrm{~g}$ you get 20 Birr (40 Birr $\times 0.5=20$ Birr). If you collect $120 \mathrm{~g}$ you get 24 Birr $(48$ Birr $\times 0.5=24$ Birr $)$. If you collect 140 g you get 28 Birr (56 Birr $\times 0.5=28$ Birr $)$. 
(fr) Your payment will be determined as follows. We offer you a payment for this task which depends on how many beans you pick from the shallow bucket and put in the other bucket. The more beans there are, the higher your payment will be. We will weigh your other bucket after the task to determine the amount of your payment. However, you may not keep all the payment for yourself. You have to return to us a fixed payment of 20 Birr for being allowed to do the task, but the rest of the payment is yours and will be given to you at the end of the day.

For instance: You get 100 Birr per $40 \mathrm{~g}$ and the rent is 20 Birr. If you collect $100 \mathrm{~g}$ then you get 20 Birr (40 Birr -20 Birr $=20$ Birr). If you collect $120 \mathrm{~g}$ then you get 28 Birr (48 Birr -20 Birr $=28$ Birr). If you collect $140 \mathrm{~g}$ then you get 36 Birr (56 Birr - 20 Birr = 36 Birr).

(ow) Your payment will be determined as follows. We offer you a payment for this task which depends on how many beans you pick from the shallow bucket and put in the other bucket. The more beans there are, the higher your payment will be. We will weigh your other bucket after the task to determine the amount of your payment.

For instance: You get 40 Birr per $20 \mathrm{~g}$. If you collect $100 \mathrm{~g}$ then you get 40 Birr. If you collect $120 \mathrm{~g}$ then you get 48 Birr. If you collect $140 \mathrm{~g}$ then you get 56 Birr.

Please, raise your hand now if you are not sure whether you understood the game. If you did not, the interviewers will help you with individual explanations.

\section{A.2 Variable definitions}

\section{A.2.1 Outcome variable}

The outcome variable of interest is the real-effort output in the experiment. This variable is measured in grams and comes from weighing the participant's sorted beans on a scale after the experimental real-effort task.

\section{A.2.2 Treatment variables}

The treatment variables are the different contracts commonly found in Ethiopian agriculture. These are binary indicators equal to one if the contract applies, that is, either fixed wage, sharecropping, fixed rent, or ownership contract, and zero otherwise. The contracts were randomly assigned to the different sessions.

\section{A.2.3 Controls A}

Controls A are set out in Table 2. They include a number of subject characteristics such as the binary indicator whether the head of the household is female, the age of the head, the age of the head squared, whether the household is a member of a 
socio-political organization such as a cooperative, whether the participant is literate, and whether the participant belongs to an ethnic minority.

\section{A.2.4 Controls B}

Controls B are set out in Table A1. They include a count of the household members in the age group $0-5$, in the age group $6-11$, in the age group $12-17$, in the age group $18-64$ and over 65 years of age.

\section{A.2.5 Controls C}

Controls C are set out in Table A1. They include a number of agricultural production characteristics such as whether the household applied fertilizer, employed wage workers, used a hoe, or used a saddle on their own plots and on plots they were renting or sharecropping. They include controls for the most common crops planted, such as white teff, other teff, barley, wheat, maize, millet and beans, all of which are binary indicators. Finally, they include a dummy variable for plough-positive areas.

\section{A.2.6 Controls D}

Controls D are set out in Table A1. They include variables on whether households benefited from government programmes, such as the sustainable land management programme, the infrastructure programme, and the savings and credit programme, and whether the household belonged to a self-help group, all of which are binary indicators.

\section{A.2.7 Other variables}

We have two other variables: a binary indicator whether the participant is a real-life sharecropper, and a binary indicator whether the participant was living in the region of Amhara. 


\section{A.3 Balance checks}

Table A1. Descriptive statistics and balance of sample, Covariates B, C and D

\begin{tabular}{|c|c|c|c|c|c|c|}
\hline & $\begin{array}{c}\text { Fixed } \\
\text { wage } \\
(1)\end{array}$ & $\begin{array}{l}\text { Share- } \\
\text { cropping } \\
\text { (2) }\end{array}$ & $\begin{array}{c}\text { Fixed } \\
\text { rent } \\
(3)\end{array}$ & $\begin{array}{l}\text { Ownership } \\
\text { (4) }\end{array}$ & $\begin{array}{l}\text { Total } \\
\text { (5) }\end{array}$ & $\begin{array}{c}P \text {-value } \\
\text { of } F \text {-test } \\
\text { (6) }\end{array}$ \\
\hline \multicolumn{7}{|l|}{ Covariates B } \\
\hline Household members $0-5$ years & $\begin{array}{c}0.68 \\
(0.69)\end{array}$ & $\begin{array}{c}0.71 \\
(0.67)\end{array}$ & $\begin{array}{c}0.73 \\
(0.87)\end{array}$ & $\begin{array}{c}0.62 \\
(0.63)\end{array}$ & $\begin{array}{c}0.69 \\
(0.72)\end{array}$ & 0.579 \\
\hline Household members $6-11$ years & $\begin{array}{c}1.23 \\
(0.93)\end{array}$ & $\begin{array}{c}1.30 \\
(0.98)\end{array}$ & $\begin{array}{c}1.24 \\
(0.99)\end{array}$ & $\begin{array}{c}1.28 \\
(0.91)\end{array}$ & $\begin{array}{c}1.26 \\
(0.95)\end{array}$ & 0.958 \\
\hline Household members 12-17 years & $\begin{array}{c}1.22 \\
(0.92)\end{array}$ & $\begin{array}{c}1.40 \\
(1.03)\end{array}$ & $\begin{array}{c}1.18 \\
(0.95)\end{array}$ & $\begin{array}{c}1.01 \\
(0.82)\end{array}$ & $\begin{array}{c}1.20 \\
(0.94)\end{array}$ & 0.022 \\
\hline Household members 18-64 years & $\begin{array}{c}2.75 \\
(1.11)\end{array}$ & $\begin{array}{c}2.78 \\
(1.23)\end{array}$ & $\begin{array}{c}2.87 \\
(1.12)\end{array}$ & $\begin{array}{c}2.58 \\
(1.03)\end{array}$ & $\begin{array}{c}2.75 \\
(1.13)\end{array}$ & 0.024 \\
\hline Household members over 65 years & $\begin{array}{c}0.05 \\
(0.21)\end{array}$ & $\begin{array}{c}0.10 \\
(0.30)\end{array}$ & $\begin{array}{c}0.06 \\
(0.28)\end{array}$ & $\begin{array}{c}0.05 \\
(0.23)\end{array}$ & $\begin{array}{c}0.06 \\
(0.25)\end{array}$ & 0.392 \\
\hline \multicolumn{7}{|l|}{ Covariates C } \\
\hline Apply fertilizer & $\begin{array}{c}0.89 \\
(0.31)\end{array}$ & $\begin{array}{c}0.93 \\
(0.25)\end{array}$ & $\begin{array}{c}0.95 \\
(0.22)\end{array}$ & $\begin{array}{c}0.87 \\
(0.33)\end{array}$ & $\begin{array}{c}0.91 \\
(0.28)\end{array}$ & 0.340 \\
\hline Employ wage workers & $\begin{array}{c}0.85 \\
(0.36)\end{array}$ & $\begin{array}{c}0.88 \\
(0.33)\end{array}$ & $\begin{array}{c}0.92 \\
(0.28)\end{array}$ & $\begin{array}{c}0.91 \\
(0.29)\end{array}$ & $\begin{array}{c}0.89 \\
(0.32)\end{array}$ & 0.167 \\
\hline Use a hoe & $\begin{array}{c}0.17 \\
(0.38)\end{array}$ & $\begin{array}{c}0.09 \\
(0.29)\end{array}$ & $\begin{array}{c}0.28 \\
(0.45)\end{array}$ & $\begin{array}{c}0.24 \\
(0.43)\end{array}$ & $\begin{array}{c}0.19 \\
(0.40)\end{array}$ & 0.010 \\
\hline Use a saddle & $\begin{array}{c}0.39 \\
(0.49)\end{array}$ & $\begin{array}{c}0.38 \\
(0.49)\end{array}$ & $\begin{array}{c}0.41 \\
(0.49)\end{array}$ & $\begin{array}{c}0.35 \\
(0.48)\end{array}$ & $\begin{array}{c}0.38 \\
(0.49)\end{array}$ & 0.636 \\
\hline On other plots (indicator variables) & & & & & & \\
\hline Apply fertilizer & $\begin{array}{c}0.55 \\
(0.50)\end{array}$ & $\begin{array}{c}0.53 \\
(0.50)\end{array}$ & $\begin{array}{c}0.53 \\
(0.50)\end{array}$ & $\begin{array}{c}0.47 \\
(0.50)\end{array}$ & $\begin{array}{c}0.52 \\
(0.50)\end{array}$ & 0.836 \\
\hline Employ wage workers & $\begin{array}{c}0.26 \\
(0.44)\end{array}$ & $\begin{array}{c}0.22 \\
(0.41)\end{array}$ & $\begin{array}{c}0.14 \\
(0.35)\end{array}$ & $\begin{array}{c}0.18 \\
(0.38)\end{array}$ & $\begin{array}{c}0.20 \\
(0.40)\end{array}$ & 0.547 \\
\hline Use a hoe & $\begin{array}{c}0.06 \\
(0.23)\end{array}$ & $\begin{array}{c}0.06 \\
(0.24)\end{array}$ & $\begin{array}{c}0.09 \\
(0.29)\end{array}$ & $\begin{array}{c}0.09 \\
(0.29)\end{array}$ & $\begin{array}{c}0.07 \\
(0.26)\end{array}$ & 0.193 \\
\hline Use a saddle & $\begin{array}{c}0.28 \\
(0.45)\end{array}$ & $\begin{array}{c}0.22 \\
(0.41)\end{array}$ & $\begin{array}{c}0.23 \\
(0.42)\end{array}$ & $\begin{array}{c}0.17 \\
(0.38)\end{array}$ & $\begin{array}{c}0.23 \\
(0.42)\end{array}$ & 0.145 \\
\hline
\end{tabular}


Table A1. (Continued)

\begin{tabular}{|c|c|c|c|c|c|c|}
\hline & $\begin{array}{c}\text { Fixed } \\
\text { wage } \\
(1)\end{array}$ & $\begin{array}{c}\text { Share- } \\
\text { cropping } \\
(2)\end{array}$ & $\begin{array}{c}\text { Fixed } \\
\text { rent } \\
(3)\end{array}$ & $\begin{array}{c}\text { Ownership } \\
(4)\end{array}$ & $\begin{array}{c}\text { Total } \\
\text { (5) }\end{array}$ & $\begin{array}{c}P \text {-value } \\
\text { of } F \text {-test } \\
(6)\end{array}$ \\
\hline \multicolumn{7}{|l|}{ Crops planted (indicator variables): } \\
\hline White teff & $\begin{array}{c}0.58 \\
(0.49)\end{array}$ & $\begin{array}{c}0.64 \\
(0.48)\end{array}$ & $\begin{array}{c}0.39 \\
(0.49)\end{array}$ & $\begin{array}{c}0.35 \\
(0.48)\end{array}$ & $\begin{array}{c}0.49 \\
(0.50)\end{array}$ & 0.117 \\
\hline Other teff & $\begin{array}{c}0.38 \\
(0.49)\end{array}$ & $\begin{array}{c}0.41 \\
(0.49)\end{array}$ & $\begin{array}{c}0.41 \\
(0.49)\end{array}$ & $\begin{array}{c}0.31 \\
(0.46)\end{array}$ & $\begin{array}{c}0.38 \\
(0.49)\end{array}$ & 0.384 \\
\hline Barley & $\begin{array}{c}0.21 \\
(0.41)\end{array}$ & $\begin{array}{c}0.23 \\
(0.42)\end{array}$ & $\begin{array}{c}0.21 \\
(0.41)\end{array}$ & $\begin{array}{c}0.19 \\
(0.40)\end{array}$ & $\begin{array}{c}0.21 \\
(0.41)\end{array}$ & 0.997 \\
\hline Wheat & $\begin{array}{c}0.52 \\
(0.50)\end{array}$ & $\begin{array}{c}0.41 \\
(0.49)\end{array}$ & $\begin{array}{c}0.34 \\
(0.47)\end{array}$ & $\begin{array}{c}0.35 \\
(0.48)\end{array}$ & $\begin{array}{c}0.41 \\
(0.49)\end{array}$ & 0.626 \\
\hline Maize & $\begin{array}{c}0.48 \\
(0.50)\end{array}$ & $\begin{array}{c}0.25 \\
(0.44)\end{array}$ & $\begin{array}{c}0.53 \\
(0.50)\end{array}$ & $\begin{array}{c}0.69 \\
(0.46)\end{array}$ & $\begin{array}{c}0.49 \\
(0.50)\end{array}$ & 0.183 \\
\hline Millet & $\begin{array}{c}0.13 \\
(0.34)\end{array}$ & $\begin{array}{c}0.03 \\
(0.16)\end{array}$ & $\begin{array}{c}0.26 \\
(0.44)\end{array}$ & $\begin{array}{c}0.26 \\
(0.44)\end{array}$ & $\begin{array}{c}0.17 \\
(0.37)\end{array}$ & 0.047 \\
\hline Beans & $\begin{array}{c}0.33 \\
(0.47)\end{array}$ & $\begin{array}{c}0.23 \\
(0.42)\end{array}$ & $\begin{array}{c}0.19 \\
(0.39)\end{array}$ & $\begin{array}{c}0.23 \\
(0.42)\end{array}$ & $\begin{array}{c}0.25 \\
(0.43)\end{array}$ & 0.801 \\
\hline Plough positive area & $\begin{array}{c}0.89 \\
(0.31)\end{array}$ & $\begin{array}{c}0.97 \\
(0.16)\end{array}$ & $\begin{array}{c}0.70 \\
(0.46)\end{array}$ & $\begin{array}{c}0.73 \\
(0.45)\end{array}$ & $\begin{array}{c}0.83 \\
(0.38)\end{array}$ & 0.061 \\
\hline \multicolumn{7}{|c|}{ Covariates D } \\
\hline \multicolumn{7}{|c|}{ Government programme (indicator variable) } \\
\hline Sustainable land management & $\begin{array}{c}0.74 \\
(0.44)\end{array}$ & $\begin{array}{c}0.74 \\
(0.44)\end{array}$ & $\begin{array}{c}0.72 \\
(0.45)\end{array}$ & $\begin{array}{c}0.74 \\
(0.44)\end{array}$ & $\begin{array}{c}0.74 \\
(0.44)\end{array}$ & 0.997 \\
\hline Infrastructure & $\begin{array}{c}0.37 \\
(0.48)\end{array}$ & $\begin{array}{c}0.32 \\
(0.47)\end{array}$ & $\begin{array}{c}0.26 \\
(0.44)\end{array}$ & $\begin{array}{c}0.33 \\
(0.47)\end{array}$ & $\begin{array}{c}0.32 \\
(0.47)\end{array}$ & 0.005 \\
\hline Savings and Credit programme & $\begin{array}{c}0.47 \\
(0.50)\end{array}$ & $\begin{array}{c}0.42 \\
(0.50)\end{array}$ & $\begin{array}{c}0.53 \\
(0.50)\end{array}$ & $\begin{array}{c}0.57 \\
(0.50)\end{array}$ & $\begin{array}{c}0.50 \\
(0.50)\end{array}$ & 0.240 \\
\hline Self-help group programme & $\begin{array}{c}0.28 \\
(0.45)\end{array}$ & $\begin{array}{c}0.28 \\
(0.45)\end{array}$ & $\begin{array}{c}0.27 \\
(0.44)\end{array}$ & $\begin{array}{c}0.25 \\
(0.43)\end{array}$ & $\begin{array}{c}0.27 \\
(0.44)\end{array}$ & 0.509 \\
\hline
\end{tabular}

Notes: Means and standard deviations in parentheses. Standard errors are clustered at the session level for the $P$-value of the $F$-test in column (6). Significance levels at ${ }^{*} P<0.10,{ }^{* *} P<0.05,{ }^{* * *} P<0.01$. 


\section{Supporting Information}

Additional Supporting Information may be found in the online version of this article:

Appendix S1. Additional analyses.

Appendix S2. Robustness checks.

Appendix S3. Impressions laboratory-in-the-field setting. 